\title{
Millennial-Scale Carbon Storage in Natural Pine Forests of the North Carolina Lower Coastal Plain: Effects of Artificial Drainage in a Time of Rapid Sea Level Rise
}

\author{
Maricar Aguilos ${ }^{1, *} \mathbb{0}$, Charlton Brown ${ }^{1}$, Kevan Minick ${ }^{1}$, Milan Fischer ${ }^{2}$, Omoyemeh J. Ile ${ }^{1}$, Deanna Hardesty ${ }^{1}$, \\ Maccoy Kerrigan ${ }^{1}$, Asko Noormets ${ }^{3}{ }^{10}$ and John King ${ }^{1}$ \\ 1 Department of Forestry and Environmental Resources, North Carolina State University, \\ Raleigh, NC 27695, USA; cfbrown@ncsu.edu (C.B.); kjminick@ncsu.edu (K.M.); ojile@ncsu.edu (O.J.I.); \\ dmhardes@ncsu.edu (D.H.); mdkerrig@ncsu.edu (M.K.); john_king@ncsu.edu (J.K.) \\ 2 Global Change Research Institute of the Czech Academy of Sciences, 60300 Brno, Czech Republic; \\ fischer.m@czechglobe.cz \\ 3 Department of Ecology and Conservation Biology, Texas A\&M University, College Station, TX 77843, USA; \\ noormets@tamu.edu \\ * Correspondence: mmaguilo@ncsu.edu
}

\section{check for}

updates

Citation: Aguilos, M.; Brown, C. Minick, K.; Fischer, M.; Ile, O.J.; Hardesty, D.; Kerrigan, M.; Noormets, A.; King, J. Millennial-Scale Carbon Storage in Natural Pine Forests of the North Carolina Lower Coastal Plain: Effects of Artificial Drainage in a Time of Rapid Sea Level Rise. Land 2021, 10 , 1294. https://doi.org/10.3390/ land10121294

Academic Editor: Richard C. Smardon

Received: 8 November 2021

Accepted: 24 November 2021

Published: 25 November 2021

Publisher's Note: MDPI stays neutral with regard to jurisdictional claims in published maps and institutional affiliations.

Copyright: (c) 2021 by the authors. Licensee MDPI, Basel, Switzerland. This article is an open access article distributed under the terms and conditions of the Creative Commons Attribution (CC BY) license (https:/ / creativecommons.org/licenses/by/ $4.0 /)$.
Abstract: Coastal forested wetlands provide important ecosystem services along the southeastern region of the United States, but are threatened by anthropogenic and natural disturbances. Here, we examined the species composition, mortality, aboveground biomass, and carbon content of vegetation and soils in natural pine forests of the lower coastal plain in eastern North Carolina, USA. We compared a forest clearly in decline (termed "ghost forest") adjacent to a roadside canal that had been installed as drainage for a road next to an adjacent forest subject to "natural" hydrology, unaltered by human modification (termed "healthy forest"). We also assessed how soil organic carbon (SOC) accumulation changed over time using ${ }^{14} \mathrm{C}$ radiocarbon dating of wood sampled at different depths within the peat profile. Our results showed that the ghost forest had a higher tree density at 687 trees ha ${ }^{-1}$, and was dominated by swamp bays (Persea palustric), compared to the healthy forest, which had 265 trees ha $^{-1}$ dominated by pond pine (Pinus serotina Michx). Overstory tree mortality of the ghost forest was nearly ten times greater than the healthy forest $(p<0.05)$, which actually contributed to higher total aboveground biomass (55.9 $\pm 12.6 \mathrm{Mg} \mathrm{C} \mathrm{ha}^{-1}$ vs. $27.9 \pm 8.7 \mathrm{Mg} \mathrm{ha}^{-1}$ in healthy forest), as the dead standing tree biomass (snags) added to that of an encroaching woody shrub layer during ecosystem transition. Therefore, the total aboveground $C$ content of the ghost forest, $33.98 \pm 14.8 \mathrm{MgC} \mathrm{ha}^{-1}$, was higher than the healthy forest, $24.7 \pm 5.2 \mathrm{Mg} \mathrm{C} \mathrm{ha}^{-1}(p<0.05)$. The total SOC stock down to a $2.3 \mathrm{~m}$ depth in the ghost forest was $824.1 \pm 46.2 \mathrm{Mg} \mathrm{C}^{-1}$, while that of the healthy forest was $749.0 \pm 170.5 \mathrm{Mg} \mathrm{C} \mathrm{ha}^{-1}(p>0.05)$. Carbon dating of organic sediments indicated that, as the sample age approaches modern times (surface layer year 2015), the organic soil accumulation rate (1.11 to $1.13 \mathrm{~mm}_{\text {year }}{ }^{-1}$ ) is unable to keep pace with the estimated rate of recent sea level rise ( 2.1 to $2.4 \mathrm{~mm}_{\text {year }}{ }^{-1}$ ), suggesting a causative relationship with the ecosystem transition occurring at the site. Increasing hydrologic stress over recent decades appears to have been a major driver of ecosystem transition, that is, ghost forest formation and woody shrub encroachment, as indicated by the far higher overstory tree mortality adjacent to the drainage ditch, which allows the inland propagation of hydrologic/salinity forcing due to SLR and extreme storms. Our study documents $\mathrm{C}$ accumulation in a coastal wetland over the past two millennia, which is now threatened due to the recent increase in the rate of SLR exceeding the natural peat accumulation rate, causing an ecosystem transition with unknown consequences for the stored C; however, much of it will eventually be returned to the atmosphere. More studies are needed to determine the causes and consequences of coastal ecosystem transition to inform the modeling of future coastal wetland responses to environmental change and the estimation of regional terrestrial $\mathrm{C}$ stocks and flux.

Keywords: ghost forest; forested wetland; aboveground biomass; soil carbon; carbon dating 


\section{Introduction}

Wetlands occupy 4-6\% of Earth's land area and store C in the range of 202-535 Gt [1,2]. The importance of wetlands in providing habitats for diverse plants and animals, and a range of other ecosystem services, is well-recognized, but a sufficient understanding of the aboveground and belowground carbon cycling of wetlands is not well-understood $[3,4]$. Wetlands are a significant type of ecosystem of the southeastern USA coastal plain. However, natural and anthropogenic disturbances threaten the ecological integrity and $C$ storage function of coastal wetland ecosystems.

Climate change threatens wetland ecosystems by exacerbating environmental stressors, which could have effects on the biodiversity, wetland productivity, and resilience to other stressors [5-8]. How climate change affects such wetland ecosystem functions has been given relatively little attention $[9,10]$. Climate change is expected to accelerate sea level rise (SLR) to between 0.4 and $1.2 \mathrm{~m}$ by 2100 [6], and alter the frequency and intensity of coastal storms [11]. Recently, it was recognized that the formation of "ghost forests", created by the submergence of low-lying land, is one of the most obvious indicators of climate change [12]. SLR also increases saltwater intrusion into freshwater ecosystems [13-15] and alters the distribution and quantity of carbon within coastal wetlands, causing species shifts and landward migration, contributing to the direct loss of wetland area [10]. Shifts in species composition in response to SLR may cause lower marsh species to replace upper marsh species as wetlands move landward and as the continental margin adjusts [16].

In addition to these climatic impacts, the draining of coastal wetlands across the southeastern USA persisted well into the 1970s and has only slowed in the past 30 years [12]. During that time, the US government decided to drain the wetlands to decrease the groundwater level for flood control and more viable crop and timber production, construction of access roads, and other land uses [17]. Eastern North Carolina was extensively ditched over many years, and one area formerly managed for timber is now the Alligator River National Wildlife Refuge (ARNWR) in Dare County, administered by the US Fish and Wildlife Service [18]. Typical lower coastal plain road construction consisted of digging a ditch connected to a major tributary, sound or other waterway to provide drainage, and using the resulting "borrow" material as the bed for the adjacent road. Such roads run throughout ARNWR and across the southeastern lower coastal plain [18].

The effect of ditching on groundwater hydrology and drainage for a given site varies depending on the location relative to the ditch. Visual observations, whether from the ground or remotely-sensed (Figure 1), indicate that in eastern NC, vegetation on the side of the road with a ditch is often dead or dying, while on the other side the vegetation is much healthier/abundant/productive. Ditches were implicated in allowing saltwater to move inland into ecosystems that are not salt-tolerant [12], yet disentangling the hydrologic effects from the salinity effects of coastal forest decline is still a developing science.

Wetland productivity is mediated by complex bio-geomorphic feedbacks, whereby plants accumulate organic matter and trap inorganic sediments to maintain their elevation in relation to local groundwater or adjacent water bodies $[19,20]$. The soil accretion capacity of coastal wetlands is a key factor in the overall resilience to environmental change [20-22]. Quantifying primary biomass production and soil organic carbon (SOC) storage in wetland forests is therefore critical for predicting the fate of coastal wetlands and the associated ecosystem services as the continental margin adjusts to SLR.

Wetlands contain $20-30 \%$ of the estimated 1500 Pg of global soil carbon [4] making them a significant global storehouse for $\mathrm{C}$. The anoxic condition of wetland soils slows down the decomposition process, resulting in the accumulation of organic matter. Thus, wetlands can store a large amount of carbon, making them an important sink of atmospheric carbon. Wetland $\mathrm{C}$ stocks vary in response to factors, including salinity, regional climate, water chemistry, soil type, lateral and vertical variability in soil properties, and vegetation, which complicates quantification of process rates [23,24]. These complexities limit our understanding of the quantity and distribution of stored carbon in wetlands [2,4]. Therefore, a more accurate approach to wetland soil carbon accounting must be used to develop 
models relating the $\mathrm{C}$ dynamics to temporal trends in wetlands. Techniques such as radiocarbon dating markers to determine the geochronology of a series of plant macrofossils are useful tools to estimate carbon accumulation rates, and were used to integrate the ages of fossils from 2000-3000 years ago [25]. The radiocarbon dating of plant material found at depth in peat profiles near ARNWR was also used to recreate historical patterns of past vegetation dynamics/marsh accretion as a means of sea level reconstruction over the recent geologic past $[19,25]$.

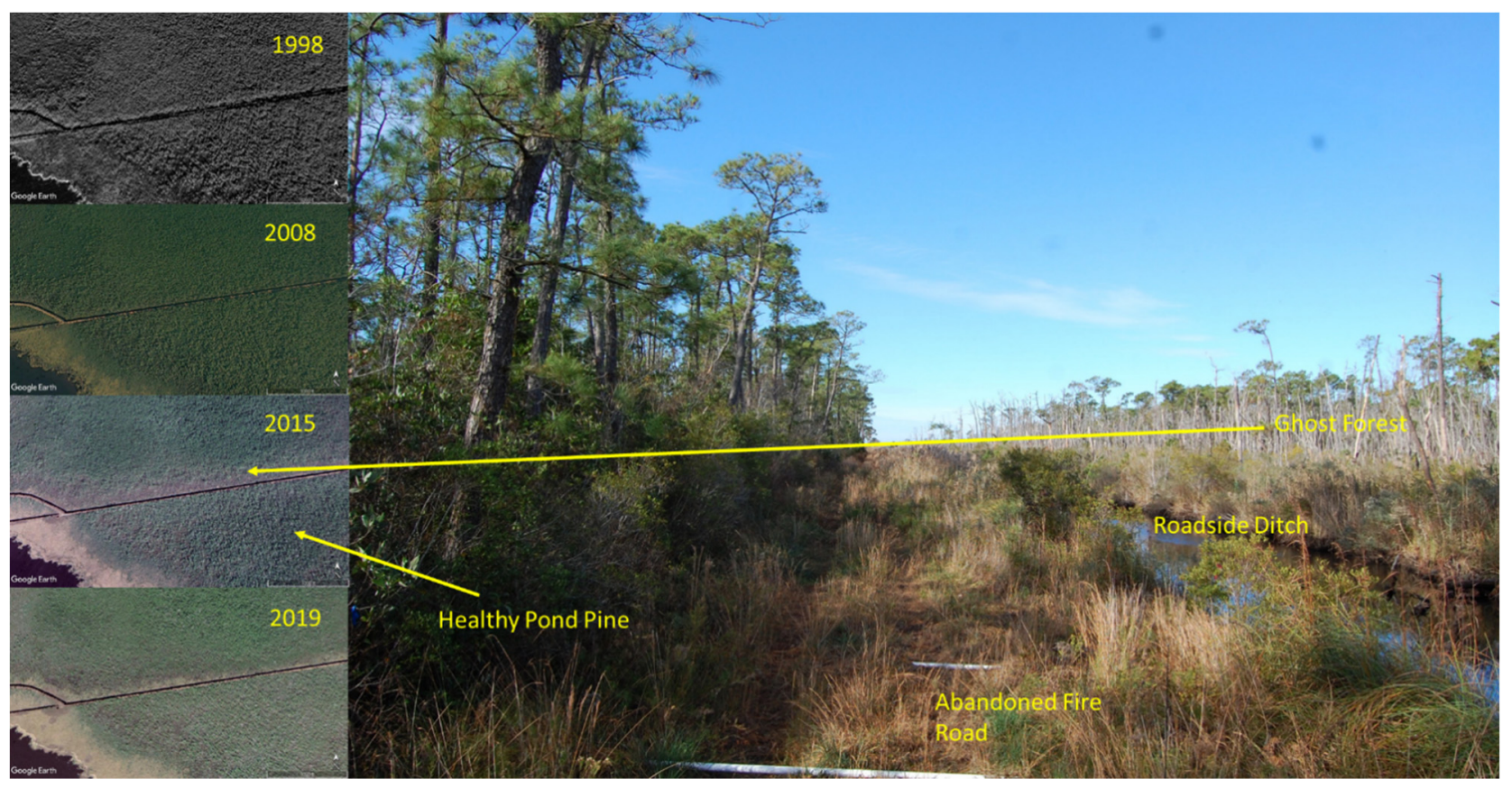

Figure 1. Time series of Google Earth-Landsat images and a ground-based picture in 2015 of the field site of the current study in the northern part of the Alligator River National Wildlife Refuge, Dare County, North Carolina, USA. In 1998 and 2008, virtually all of the satellite image area hosted healthy pond pine forest, whereas, by 2015, significant areas of ghost forest were present (grey color) and coastal marsh (beige color) was expanding. The bank of East Lake is visible in the lower left (dark color). Satellite images show a perspective of approximately $1163 \mathrm{~m}$ altitude. Field site elevation is approximately $30 \mathrm{~cm}$ AMSL. Photo credit: John King.

In this study, we quantified the vegetation structure and $C$ storage of two adjacent natural wetland pine forests as affected by millennial-scale SLR and century-scale artificial drainage at ARNWR, in eastern North Carolina, USA. We estimated the biomass of vegetation at different levels of the overstory canopy and evaluated tree mortality and species composition. We also estimated the total carbon stock in vegetation and soils and how these changed as a function of distance from local water bodies/open water. Further, we assessed the rate of SOC accumulation using ${ }^{14} \mathrm{C}$ radiocarbon dating on wood samples collected at different depths within the peat profile down to the underlying Pleistocene mineral sedimentary deposits, spanning approximately 1800 years BP, and related findings to local sea level reconstructions. We hypothesized that the ghost forest, which has a visibly high mortality (e.g., Figure 1), would have lower total C stocks (in vegetation and soils) compared to adjacent healthy forests. We also hypothesized that ecosystem $C$ storage would be positively correlated with the distance from open water, due to protection from salinity and/or hydrologic stress. Finally, we hypothesized that the recent decades-long visible increase in ghost forests would be associated with recent decadal-scale change in the rate of local SLR as revealed by the ${ }^{14} \mathrm{C}$ dating estimation of marsh accretion over the past two millennia. 


\section{Methods}

\subsection{Study Site}

This study was conducted in the northern reaches of the Alligator River National Wildlife Refuge (ARNWR) in Dare County, North Carolina (Figure 2), which spans over 61,600 hectares [18]. The wetlands physiography of ARNWR is a product of post-Wisconsinian glaciation, as coastal rivers cut channels through the landscape at a time of lower sea level that consequently filled with marine sediments overlain by accumulating organic peat $[26,27]$. The soil at this site is classified as a Belhaven series histosol (loamy, mixed, dystic, thermic Terric Haplosaprists) with a highly decomposed organic matter layer underlain by loamy marine sediments [28]. This part of the refuge, adjacent to the water bodies of Albemarle Sound and East Lake, was historically dominated by extensive pond pine forest due to this species' tolerance of hydric soil conditions and dependence on fire for regeneration [18,29]. An abandoned fire road with adjacent drainage ditch, built in 1965 (Ed Sawyer Road) (Figures 1 and 2), provided an ideal location to observe the effects of altered hydrology and the distance from surrounding water bodies on pond pine forest carbon storage and ecosystem transition. Common overstory species at the study site include swamp bay (Persea palustris), pond pine (Pinus serotina), red maple (Acer rubrum) and sweetgum (Liquidambar styraciflua), in addition to numerous understory shrubs and herbaceous plants. The elevation is approximately $30 \mathrm{~cm}$ above mean sea level, average annual precipitation is $1163 \pm 49 \mathrm{~mm}(1981-2018)$ and average annual temperature is $15.7^{\circ} \mathrm{C} \pm 0.4^{\circ} \mathrm{C}$ (2009-2018).
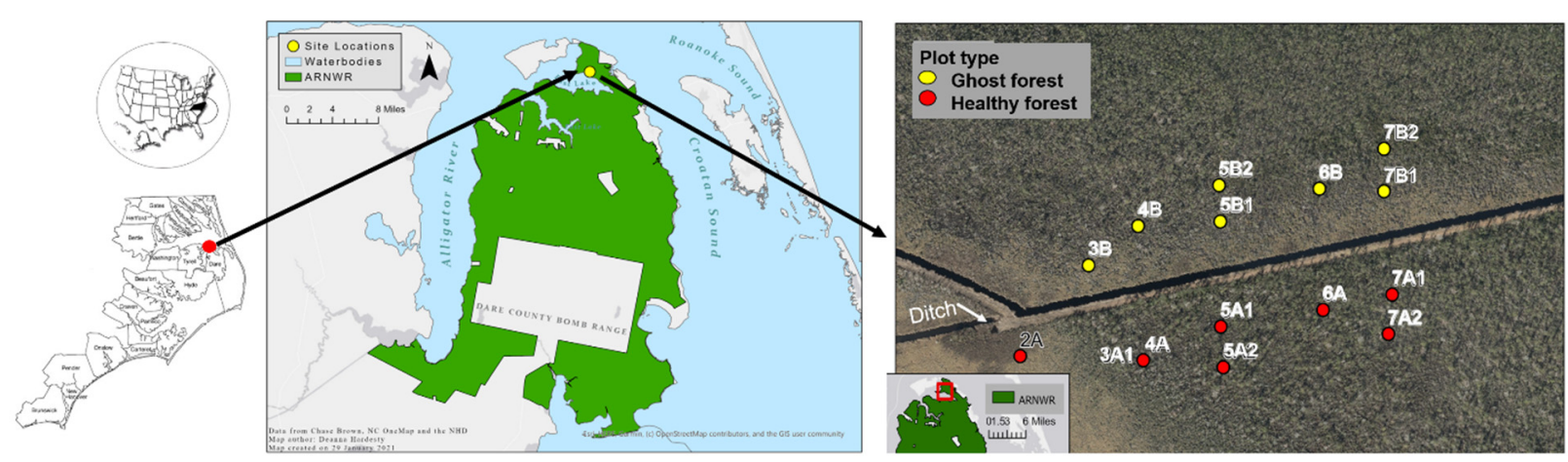

Figure 2. Location of the study site in the northern part of Alligator River National Wildlife Refuge in eastern North Carolina, USA. On the right panel, red circles denoted by their corresponding plot codes represent sampling plots of the healthy pond pine forest and yellow circles are ghost forest sampling locations. Care was taken to sample vegetation at least $100 \mathrm{~m}$ away from the ditch and roadside to minimize edge effects. East Lake/Alligator River is to the west of the study site, while the Albemarle/Croatan Sound is to the east.

\subsection{Overstory Tree Biomass and C Content}

Vegetation sampling occurred throughout 2014 and 2015. Paired, circular (15 m radius) vegetation sampling plots were installed in healthy forest and ghost forest along both sides of the fire road, starting near the bank of East Lake and progressing inland (Figure 2). Overstory tree species were identified and live/dead status was determined. All tree heights (living and dead) were measured with a Nikon laser hypsometer, and diameters were measured at breast height (1.3 m above ground level) with a D-tape. Dead trees were assigned to a decay class using USDA Forest Service Forest Inventory and Analysis (FIA) protocols [30] based on visible characteristics (Table 1). Overstory standing tree biomass was estimated using species-specific allometric relationships [31] for all overstory species (Table 1). Allometric regressions for estimating biomass of pond pine do not exist in the literature, representing a pressing research need, so equations were used for the taxonomically closely-related pitch pine (Pinus resinosus L.) [32]. Live tree C content was calculated as $50 \%$ of biomass [32], and that of dead trees as the calculated live C content adjusted by the $\%$ remaining by decay class. 
Table 1. Allometric equations and decay classes used to estimate live biomass and C content of overstory tree species at Alligator River National Wildlife Refuge in eastern, North Carolina, USA [30,32].

\begin{tabular}{|c|c|c|}
\hline \multicolumn{3}{|l|}{ Live Biomass Regressions } \\
\hline Species & Allometric Equation & Notes \\
\hline Pond pine (P. serotina) & $\mathrm{y}=\exp (2.0171+2.3373 \times \ln (\mathrm{dbh}))$ & Equation for $P$. rigida \\
\hline Red maple (A. rubrum) & $\mathrm{y}=2.52363 \times\left(\mathrm{dbh}^{2}\right)^{1.9648}$ & \\
\hline Sweetgum (L.sty raciflua) & $\mathrm{y}=1.822108 \times\left(\mathrm{dbh}^{2}\right)^{1.2635}$ & \\
\hline Bay (Persea spp.) & $\mathrm{y}=-13.388+6.82 \times\left(\mathrm{dbh}^{2}\right)$ & \\
\hline FIA decay class & Qualification & $\mathrm{C}$ remaining $(\%)$ \\
\hline 0 & Alive & 100 \\
\hline 1 & $\begin{array}{l}\text { Dead, small branches attached, } \\
\text { knife does not penetrate }\end{array}$ & 97 \\
\hline 2 & $\begin{array}{l}\text { Dead, no small branches, has large } \\
\text { branches, little penetration }\end{array}$ & 97 \\
\hline 3 & $\begin{array}{l}\text { Dead, no large branches, height } \\
\text { intact, more penetration }\end{array}$ & 86 \\
\hline 4 & $\begin{array}{c}\text { Dead, top broken, easy penetration, } \\
\text { highly decayed }\end{array}$ & 53 \\
\hline
\end{tabular}

\subsection{Mid-Story and Understory Biomass and C Content}

Mid-story biomass was sampled using $5 \mathrm{~m}$ radius circular plots nested within each overstory plot. Diameter of woody plants up to $10 \mathrm{~cm}$ diameter was measured at $10 \mathrm{~cm}$ above the ground. On-site, species-specific, allometric equations were developed to estimate mid-story, woody plant biomass. Fifty mid-story plants ranging in size and species were destructively harvested, and heights, diameters and total fresh weight were measured directly. Wood samples were cut from each plant to determine fresh-to-dry weight ratios, applied to the green biomass estimates. For small mid-story plants, biomass was estimated using the exponential equation $\mathrm{y}=0.0944 \exp ^{(0.7102 \mathrm{x})}\left(R^{2}=0.89\right)$, where $\mathrm{x}$ is the diameter-atbreast-height $(\mathrm{dbh})$. For large mid-story plants, the linear equation $\mathrm{y}=1.3229 \mathrm{x}-2.3518$ $\left(R^{2}=0.78\right)$ was used. Understory, primarily herbaceous, plant biomass was estimated by destructively harvesting $1 \times 1 \mathrm{~m}$ clip plots in the center of the mid-story plots, dried to constant mass at $65^{\circ} \mathrm{C}$, and weighed. Carbon content of all mid-story and understory plants was assumed to be $50 \%$ of live biomass.

\subsection{Soil Sampling}

Soil samples were taken with a McCauley auger at $10 \mathrm{~cm}$ increments to a depth of $1 \mathrm{~m}$ at one location in each overstory plot. Samples were sieved $(<2 \mathrm{~mm})$ and dried to constant mass at $65^{\circ} \mathrm{C}$, and weighed. Bulk density was determined by dividing mass by volume for each depth increment. Each soil increment was analyzed separately for carbon concentration, content and stable $\mathrm{C}$ isotopes using a Picarro G2201-isotopic $\mathrm{CO}_{2} / \mathrm{CH}_{4}$ analyzer with combustion module at the Tree Physiology and Ecosystem Science Laboratory, North Carolina State University, USA. Percent soil carbon and bulk density were then used to estimate the total soil carbon content. The soil bulk density and carbon content were determined using the following formula:

$$
\text { Soil bulk density }\left(\mathrm{g} \mathrm{cm}^{-3}\right)=\frac{\text { Ovendry sample mass }(\mathrm{g})}{\text { Sample volume }\left(\mathrm{cm}^{3}\right)}
$$

Soil carbon content $\left(\mathrm{g} \mathrm{C} \mathrm{cm}^{-2}\right)=$ bulk density $\left(\mathrm{g} \mathrm{cm}^{-3}\right) \times$ soil depth $(\mathrm{cm}) \times \%$ organic C

The total soil carbon pool was determined by summing the carbon mass of each of the sampled soil depths extrapolated into per hectare basis $\left(\mathrm{Mg} \mathrm{C} \mathrm{ha}^{-1}\right)$. 


\subsection{Belowground Wood Sampling}

Wood fragments were recovered from soil samples at various depths within the $1 \mathrm{~m}$ peat profile sampled with the McCauley auger, and down to $2.3 \mathrm{~m}$ depth using a bucket auger. This was the maximum peat depth encountered at the site, furthest inland from the shoreline, below which lay Pleistocene mineral sedimentary deposits. The deepest wood sample collected was embedded in the mineral sediments, in what appeared to be a buried soil A-horizon, suggesting presence of an upland forest at some point in the past. We used the radiocarbon dating method to determine the age of the buried wood samples [33]. Sixteen of these samples were sent off for ${ }^{14} \mathrm{C}$ dating at the National Ocean Sciences Accelerator Mass Spectrometry Facility at the Woods Hole Oceanographic Institution.

\subsection{Data Analysis}

We used ANOVA and Tukey's HSD Test for comparison between paired plots, testing the level of significant differences at a 95\% confidence level. Smoothed-curve fittings were carried out with locally weighted logarithmic regression in ggplot2 package [34]. Contour plots were used to present a 2-dimensional surface by plotting the aboveground $\mathrm{C}$ and SOC as contours in $\mathrm{x}$-axis (latitude) and y-axis (longitude). Contour plots were generated using plotly [35], tidyverse [36], and reshape2 [37] packages. All analyses were processed in $\mathrm{R}$ version 4.1.1 [38].

\section{Results}

\subsection{Overstory Species Composition, Tree Density, Mortality and Diameter}

Overstory species composition, tree density, and mortality differed significantly between the ghost forest and the healthy forest (Table 2). The ghost forest had a tree density of 687 trees ha ${ }^{-1}$ (Table 2), characterized by $56 \%$ swamp bay, $38 \%$ pond pine, and the remaining $5 \%$ was red maple. Sixty percent of the overstory (or 412 trees ha ${ }^{-1}$ ) in the ghost forest was standing dead or dying, half of which were swamp bay, $43 \%$ were pond pine, and the remainder were red maple. The most prominent decay class of swamp bay and pond pine in the ghost forest was class 2, characterized as dead with only large branches left. In contrast, the healthy forest had a tree density of 265 trees ha $^{-1}$ (Table 2), with $72 \%$ pond pine, $24 \%$ red maple and $4 \%$ sweetgum. The amount of standing dead trees in the healthy forest was only $17 \%$ ( 42 trees $\mathrm{ha}^{-1}$ ). Most dead trees were pond pine of decay class 1 (dead, small branches attached). Interestingly, there were no swamp bay trees in the healthy forest, a species that dominated the overstory of the ghost forest (e.g., species replacement during ecosystem transition). While the stand density of the ghost forest was over 2.5 times higher than in the healthy forest, mortality was nearly ten times greater (Table 2). The ghost forest was also characterized by having a significantly smaller diameter and height of trees than the healthy forest $(p<0.05$; Figure 3$)$.

Table 2. Overstory species composition, tree density, and decay class of dead trees in healthy forest and ghost forest in the northern part of the Alligator River National Wildlife Refuge in eastern North Carolina. Different letters after a total value denote significant differences at $p<0.05$ between ghost and healthy forest.

\begin{tabular}{cccccc}
\hline Location & $\begin{array}{c}\text { General } \\
\text { Species } \\
\text { Composition }\end{array}$ & $\begin{array}{c}\text { Healthy/No } \\
\text { Decay }\end{array}$ & $\begin{array}{c}\text { Standing } \\
\text { Dead/Dying }\end{array}$ & $\begin{array}{c}\text { Total (Healthy } \\
\text { + Standing } \\
\text { Dead) }\end{array}$ & $\begin{array}{c}\text { * Decay } \\
\text { Class of } \\
\text { Standing } \\
\text { Dead Trees }\end{array}$ \\
\hline Ghost forest & Swamp bay & 176 & 210 & 388 & 2 \\
& Maple & 12 & 24 & 36 & 1 \\
& Pitch Pine & 85 & 178 & 263 & 2 \\
& Total & $273^{\text {a }}$ & $412^{\text {a }}$ & $687^{\text {a }}$ & \\
\hline
\end{tabular}


Table 2. Cont.

\begin{tabular}{cccccc}
\hline Location & $\begin{array}{c}\text { General } \\
\text { Species } \\
\text { Composition }\end{array}$ & $\begin{array}{c}\text { Healthy/No } \\
\text { Decay }\end{array}$ & $\begin{array}{c}\text { Standing } \\
\text { Dead/Dying }\end{array}$ & $\begin{array}{c}\text { Total (Healthy } \\
\text { + Standing } \\
\text { Dead) }\end{array}$ & $\begin{array}{c}\text { * Decay } \\
\text { Class of } \\
\text { Standing } \\
\text { Dead Trees }\end{array}$ \\
\cline { 3 - 5 } Healthy forest & Maple & 63 & 2 & 65 & 1 \\
& Pitch Pine & 148 & 42 & 190 & 1 \\
& Sweetgum & 10 & 0 & 10 & \\
Total & $220^{\mathrm{b}}$ & $44^{\mathrm{b}}$ & $265^{\mathrm{b}}$ & \\
\hline
\end{tabular}

* Decay class 0-alive; 1—dead but small branches attached; 2—dead with only large branches left, 3-large branches gone; 4-top broken off, very decayed.
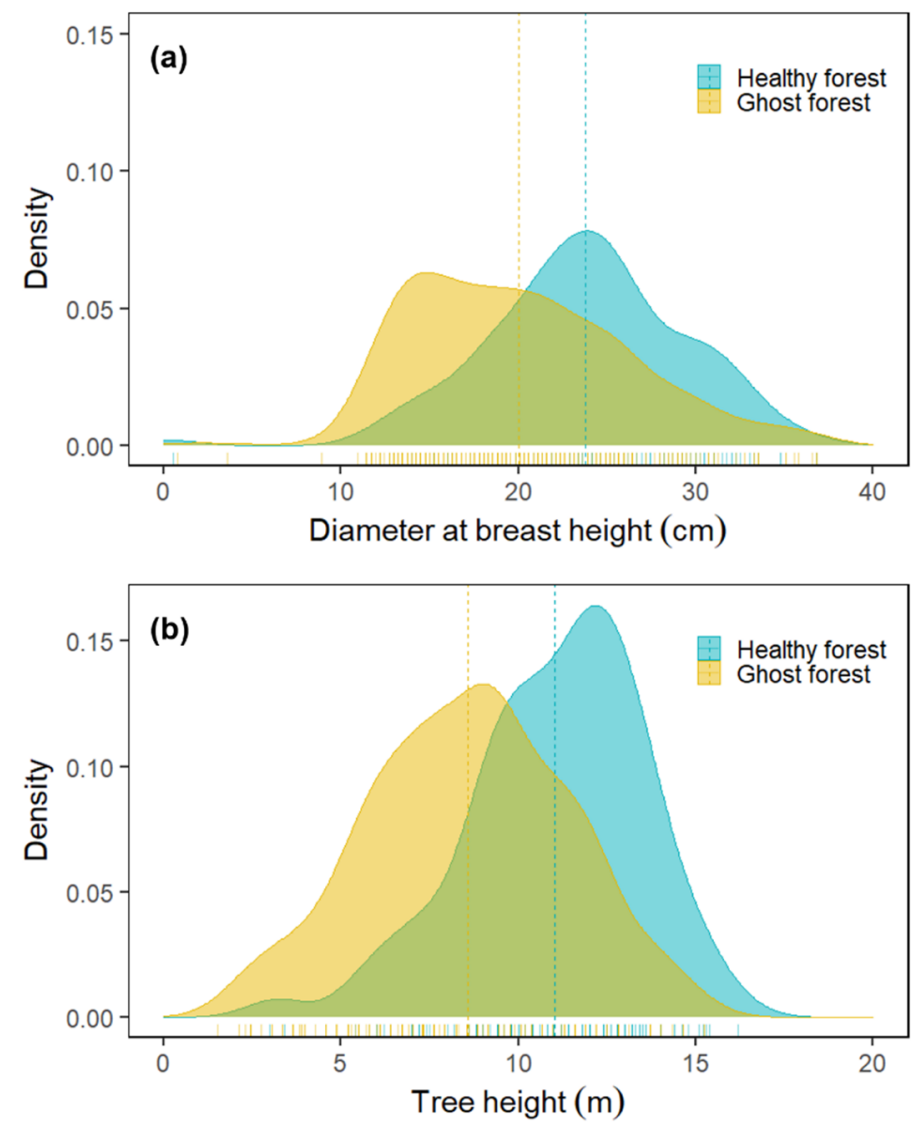

Figure 3. Diameter (a) and height (b) distributions of all species in ghost forest and healthy forest in the northern part of the Alligator River National Wildlife Refuge in eastern North Carolina. Dashed lines represent the means of each population sample.

\subsection{Overstory, Mid-Story and Understory Biomass}

Ghost forest and healthy forest differed significantly in total overstory and midstory biomass, but not in understory biomass (Table 3). On a per tree basis, the healthy forest had a higher average overstory tree biomass $\left(0.11 \mathrm{Mg} \mathrm{ha}^{-1}\right)$, which is $18 \%$ higher than in the ghost forest $\left(0.09 \mathrm{Mg} \mathrm{ha}^{-1}\right)(p<0.05)$. However, given the higher tree density in the ghost forest (Table 1), the overall total overstory biomass in the ghost forest was $55.97 \pm 12.61 \mathrm{Mg} \mathrm{ha}^{-1}$ compared to $27.99 \pm 8.75 \mathrm{Mg} \mathrm{ha}^{-1}$ in the healthy forest (Table 3). Almost $44 \%$ of the total overstory biomass in the ghost forest was in standing dead trees, however, with a total dead biomass of $25.06 \pm 6.26 \mathrm{Mg} \mathrm{ha}^{-1}$. In contrast, of the $27.99 \mathrm{Mg} \mathrm{ha}{ }^{-1}$ total overstory biomass in the healthy forest, a total of $88 \%$ was in live trees (24.81 $\pm 7.25 \mathrm{Mg} \mathrm{ha}^{-1}$ ). The remaining $11 \%$ was in standing dead trees, primarily pine (Table 3). Interestingly, the mid-story biomass $\left(3.65 \pm 2.70 \mathrm{Mg} \mathrm{ha}^{-1}\right)$ of the ghost forest was 
only $25 \%$ of the amount in the healthy forest $\left(14.06 \pm 7.30 \mathrm{Mg} \mathrm{ha}^{-1}\right)$, possibly due to the dense shrub canopy hindering the development of a mid-story in the ghost forest. Finally, understory biomass in the ghost forest averaged $8.3 \mathrm{Mg} \mathrm{ha}^{-1}$ compared to $7.4 \mathrm{Mg} \mathrm{ha}^{-1}$ in the healthy forest, but the difference was not significant due to the relatively large variance.

Table 3. Summary of biomass in each vegetation strata by species in healthy forest and ghost forest in the northern part of the Alligator National Wildlife Refuge in eastern North Carolina. Different letters after a biomass value denote significant differences at $p<0.05$ between healthy forest and ghost forest.

\begin{tabular}{|c|c|c|c|c|c|c|c|}
\hline & \multirow{2}{*}{ Species } & \multicolumn{3}{|c|}{ Overstory Biomass ( $\mathrm{Mg} \mathrm{ha}^{-1}$ ) } & \multirow{2}{*}{$\begin{array}{l}\text { Mid-Story } \\
\text { Biomass } \\
\left(\mathrm{Mg} \mathrm{ha}^{-1}\right)\end{array}$} & \multicolumn{2}{|c|}{$\begin{array}{c}\text { Under-Story Biomass } \\
\left(\mathrm{Mg} \mathrm{ha}^{-1)}\right.\end{array}$} \\
\hline & & Alive & $\begin{array}{l}\text { Standing } \\
\text { Dead }\end{array}$ & $\begin{array}{l}\text { Total BIOMASS } \\
\text { (Alive + Dead) }\end{array}$ & & & \\
\hline \multirow[t]{4}{*}{ Ghost forest } & Swamp bay & 16.35 & 10.08 & 26.43 & & & \\
\hline & Maple & 2.69 & 1.42 & 4.11 & & & \\
\hline & Pine & 11.87 & 13.57 & 25.43 & & & \\
\hline & Total & $30.91^{a} \pm 6.96$ & $25.06^{a} \pm 6.26$ & $55.97^{a} \pm 12.61$ & & $3.65^{a} \pm 2.70$ & $8.32^{a} \pm 4.1$ \\
\hline \multirow[t]{4}{*}{ Healthy forest } & Maple & 8.45 & 0.23 & 8.68 & & & \\
\hline & Pine & 15.42 & 2.96 & 18.38 & & & \\
\hline & Sweetgum & 0.93 & 0.00 & 0.93 & & & \\
\hline & Total & $24.81^{b} \pm 7.25$ & $3.19^{b} \pm 1.65$ & $27.99^{b} \pm 8.75$ & & $14.06^{b} \pm 7.30$ & $7.41^{a} \pm 1.28$ \\
\hline
\end{tabular}

The ecosystem transition from the healthy forest to the ghost forest resulted in a major shift in overstory species composition and forest structure, from dominance/codominance by pond pine/red maple to that of woody bay shrubs/(declining) pond pine, and resulting shifts in biomass distribution (Table 3). In the healthy forest, the total live overstory biomass averaged $24.8 \mathrm{Mg} \mathrm{ha}^{-1}$, with pond pine and red maple accounting for $62 \%$ and $34 \%$, respectively. In ghost forest, the total live overstory biomass of $30.9 \mathrm{Mg} \mathrm{ha}^{-1}$ was comprised of $53 \%$ bay shrubs and $38 \%$ pond pine, although the pond pine was in rapid decline (Figure 1). With this transition, the structure of the forest changed from median diameter/height of $24 \mathrm{~cm} / 11.5 \mathrm{~m}$ in the healthy forest to $20 \mathrm{~cm} / 8.5 \mathrm{~m}$ in the ghost forest (Figure 3), in addition to the increased density. Finally, the proportion of dead overstory biomass to total overstory biomass shifted from 0.16 in the healthy forest to 0.60 in the ghost forest, signifying impending large losses of ecosystem $C$ as the dead material decomposed in the coming years.

\subsection{Ecosystem Carbon Stocks in Vegetation and Soils}

As with biomass, the total ecosystem $C$ stocks differed significantly between the healthy forest and ghost forest, as did the distribution between different compartments (Figure 4). The total aboveground $\mathrm{C}$ content of ghost forest, $33.9 \mathrm{MgC} \mathrm{ha}^{-1}$, was $9.2 \mathrm{MgC} \mathrm{ha}^{-1}$ greater than that of the healthy forest at $24.7 \mathrm{Mg} \mathrm{C} \mathrm{ha}^{-1}$. The $\mathrm{C}$ content of dead trees in the ghost forest contributed to almost $44 \%$ of the total aboveground $C$, while that contribution in the healthy forest was only $11 \%$. The percentage contribution of overstory live tree $\mathrm{C}$ to the total aboveground $C$ was similar in both forests, at $45-50 \%$, but the amount was double in the ghost forest at $27.9 \mathrm{MgC} \mathrm{ha}^{-1}$, compared to healthy forest at $13.9 \mathrm{MgC} \mathrm{ha}^{-1}$. The percentage contribution of the mid-story to total aboveground $\mathrm{C}$ differed greatly between the healthy forest (28\%) and ghost forest (5\%), as did the amounts, at 7.0 and $1.8 \mathrm{MgC} \mathrm{ha}^{-1}$, respectively (Figure 4). Finally, the understory $\mathrm{C}$ content of both forests was similar at $3.7 \mathrm{Mg} \mathrm{C}^{-1}$ in the healthy forest and $4.2 \mathrm{Mg} \mathrm{C}^{-1}$ in the ghost forest, contributing $15 \%$ and $12 \%$ to total aboveground $\mathrm{C}$, respectively. 


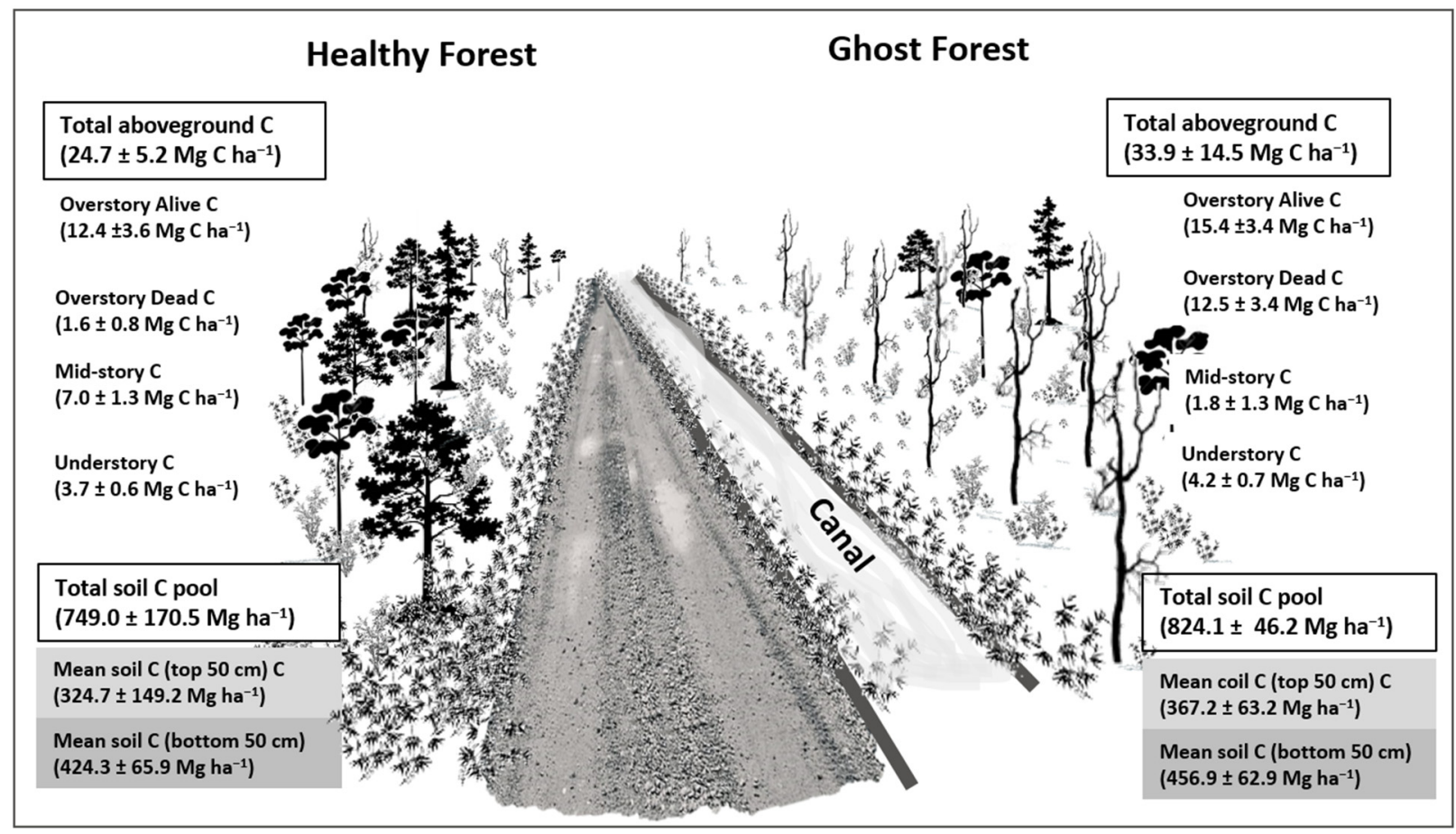

Figure 4. Estimates of aboveground (overstory, mid-story, and understory) vegetation and soil carbon stocks (0-100 $\mathrm{cm}$ depth) of healthy forest and ghost forest in the northern part of Alligator River National Wildlife Refuge in eastern North Carolina. Vegetation C stocks were calculated from biomass estimates, and thus have the same levels of statistical significance (Table 3).

\subsection{Change in Overstory C Stocks with Distance from Open Water}

The visible ecosystem transition occurring at our study site (Figures 1 and 2), was accompanied by a progression of increasing vegetation biomass $C$ and soil organic $C$ with a distance from open water. Averaged over all sampling plots, the total $C$ in overstory trees averaged $13.6 \mathrm{MgC} \mathrm{ha}^{-1}$ in the ghost forest, compared to $25.0 \mathrm{MgC} \mathrm{ha}^{-1}$ in healthy forests (Figure $5 \mathrm{a}, \mathrm{c})$. There was a correlation $\left(R^{2}=0.52\right)$ between the increasing live overstory $\mathrm{C}$ and increasing distance from open water in the healthy forest but not with the ghost forest $\left(R^{2}<0.01\right.$; Figure 6). There was a strong relationship between the increasing soil organic $C$ (SOC) with increasing distance from open water in the ghost forest $\left(R^{2}=0.60\right)$ compared to the healthy forest $\left(R^{2}=0.30\right.$; Figure $5 \mathrm{c}, \mathrm{d}$ and Figure 6$)$.

\subsection{Soil Carbon Stocks}

The mean soil organic carbon stocks across the plots in the ghost forest was $412 \mathrm{Mg} \mathrm{C} \mathrm{ha}^{-1}$, which was $37.5 \mathrm{MgC} \mathrm{ha}^{-1}$ greater than the healthy forest: $374.5 \mathrm{Mg} \mathrm{C}^{-1}$ (Figure 7). In both forests, the soil C content in the top $50 \mathrm{~cm}$ was less than the lower $50 \mathrm{~cm}$. Across the entire vertical $1 \mathrm{~m}$ soil profile, the ghost forest had a higher soil $\mathrm{C}$ than the healthy forest. The mean soil $\mathrm{C}$ in the top $50 \mathrm{~cm}$ in the ghost forest was $367.2 \mathrm{Mg} \mathrm{C} \mathrm{ha}^{-1}$ and, in the bottom $50 \mathrm{~cm}$, $456.9 \mathrm{MgC} \mathrm{ha}{ }^{-1}$, whereas the healthy forest had $324.7 \mathrm{MgC} \mathrm{ha}^{-1}$ and $424.3 \mathrm{MgC} \mathrm{ha}^{-1}$, for top $50 \mathrm{~cm}$ and below $50 \mathrm{~cm}$ depths, respectively.

\subsection{Wood Sample Carbon Dating and Soil Accumulation}

The radio-isotope of $C\left({ }^{14} \mathrm{C}\right)$ in wood samples recovered from the peat during soil sampling was used to age the soil profile and calculate peat accumulation rates (Table 4). Wood samples ranged in age from ca. AD 235 to ca. AD 1870, with a fairly strong relationship between sample age and peat soil depth in soil (Figure $8 \mathrm{a}$ ). It is notable that the deepest $(-234 \mathrm{~cm})$ and oldest $(\mathrm{AD} 235)$ wood sample was recovered from the A-horizon of a buried mineral soil profile, while all the rest were recovered from the overlying peat. 
As the sample age approached modern times, we found a decreasing soil accumulation rate (y-axis near 0, Table 4; Figure $8 \mathrm{~b}$ ). The rate of soil accumulation over time ranged from 2.59 to $7.92 \mathrm{~mm}_{\text {year }}{ }^{-1}$. To obtain the annual soil carbon accumulation rate, we divided the average carbon stock between the ghost forest and healthy forest ( $393 \mathrm{Mg} \mathrm{C} \mathrm{ha}^{-1}$ ) by the age of the wood samples following the methods of [25]. The resulting average annual carbon accumulation rate was roughly $0.21-1.67 \mathrm{MgC} \mathrm{ha}^{-1}$ year $^{-1}$.

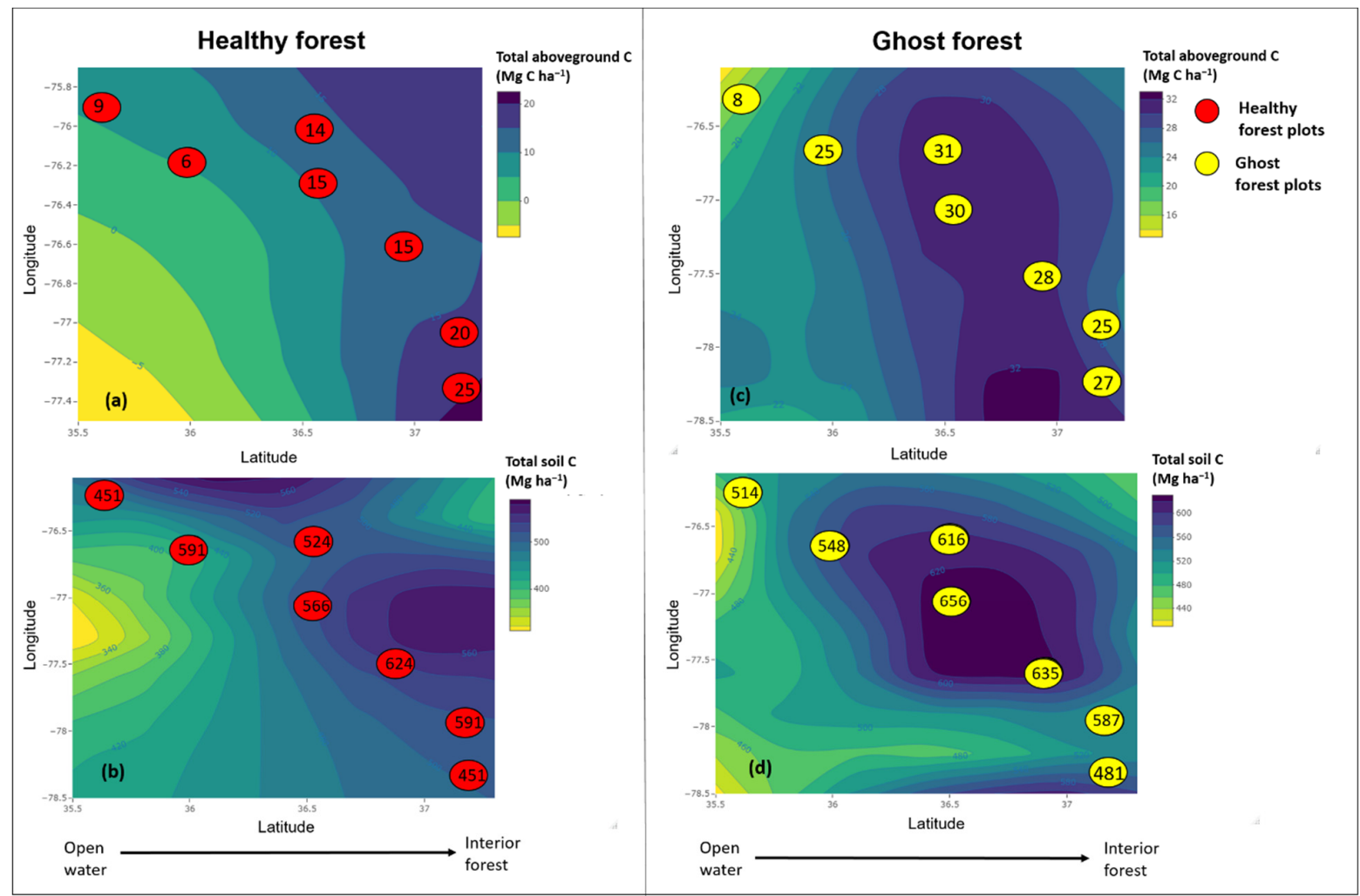

Figure 5. Map of variation in total aboveground $C$ content $(\mathbf{a}, \mathbf{b})$ and total soil $C$ content $(\mathbf{c}, \mathbf{d})$ as a function of distance from the bank of East Lake (open water) in healthy forest (left panels) and ghost forest (right panels) in the northern part of Alligator River National Wildlife Refuge in eastern North Carolina. Red circles denoted by their corresponding plot codes represent sampling plots of the healthy pond pine forest, and yellow circles are ghost forest sampling plot locations. Values inside each circle are the total aboveground $C(\mathbf{a}, \mathbf{b})$ and total soil $C(\mathbf{c}, \mathbf{d})$.
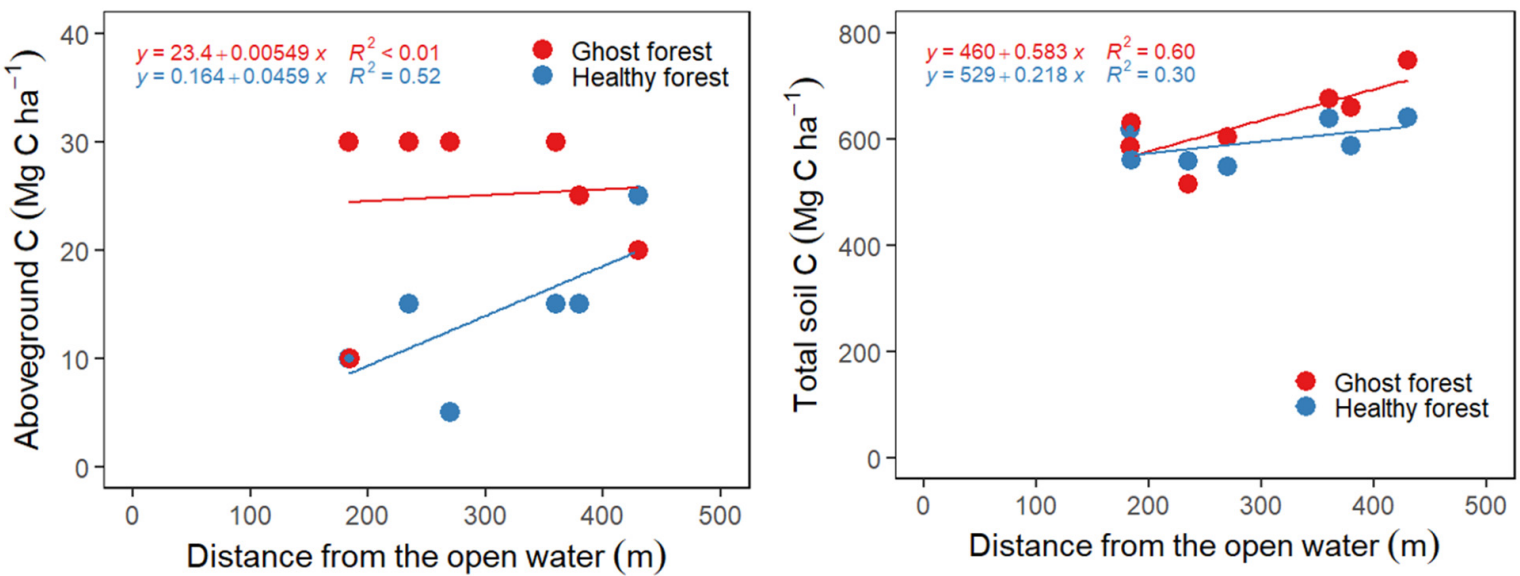

Figure 6. Relationships between aboveground C (left) and total soil C (right) with the distance from the open water in the healthy and ghost forests. 


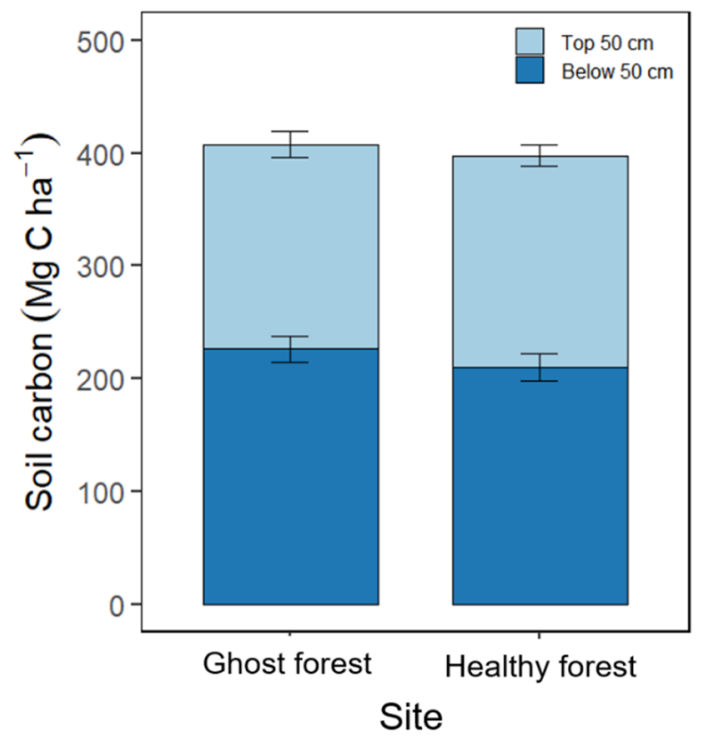

Figure 7. Soil carbon content at the ghost and healthy forest at the top $50 \mathrm{~cm}$ and below $50 \mathrm{~cm}$.
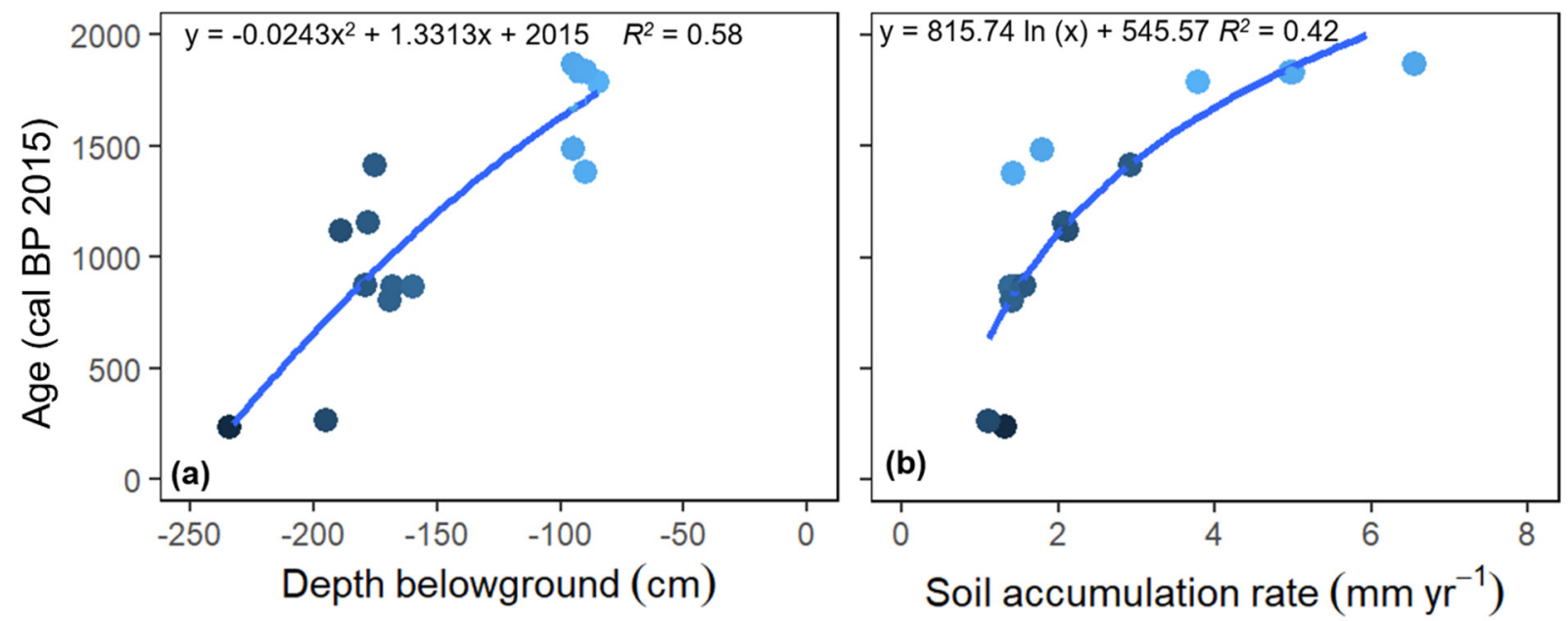

Figure 8. The relationship between the (a) depth of wood samples collected at the study sites and age (calendar year BP 2015), and (b) soil accumulation rate and age of the study site determined using the radiocarbon $\left({ }^{14} \mathrm{C}\right)$ analysis for calendar year BP 2015. A total of 16 underground wood samples were used in the analysis.

Table 4. Depth of soil where 16 wood samples were collected, the estimated age (approximate calendar year AD) and calculated soil accumulation rate using the method of McTigue et al. (2019) [26].

\begin{tabular}{ccc}
\hline Soil Depth (cm) & $\begin{array}{c}\text { Age (Apprx. Calendar Year } \\
\text { BP 2015) }\end{array}$ & $\begin{array}{c}\text { Soil Accumulation Rate } \\
\text { (mm/Year) }\end{array}$ \\
\hline-85 & 1790 & 3.78 \\
-90 & 1380 & 1.42 \\
-90 & 1835 & 5.00 \\
-92 & 1830 & 4.97 \\
-95 & 1485 & 1.79 \\
-95 & 1870 & 6.55 \\
-160 & 865 & 1.39 \\
-168 & 865 & 1.46 \\
-169 & 805 & 1.40 \\
-175 & 1415 & 2.92 \\
\hline
\end{tabular}


Table 4. Cont.

\begin{tabular}{ccc}
\hline Soil Depth (cm) & $\begin{array}{c}\text { Age (Apprx. Calendar Year } \\
\text { BP 2015) }\end{array}$ & $\begin{array}{c}\text { Soil Accumulation Rate } \\
\text { (mm/Year) }\end{array}$ \\
\hline-178 & 1155 & 2.07 \\
-179 & 875 & 1.57 \\
-189 & 1120 & 2.11 \\
-190 & 1775 & 7.92 \\
-195 & 265 & 1.11 \\
-234 & 235 & 1.31 \\
\hline
\end{tabular}

\section{Discussion}

\subsection{Species Composition and Forest Mortality}

Historical ditching and drainage along lower coastal plain roads and other infrastructure alter site hydrology, and potentially saltwater exposure regimes, in ways that affect contemporary ecosystem function, with implications for responses to future environmental change. The ditch, which provides drainage for the road, may also allow the inland intrusion of fresh- or saltwater during storm surges further than would normally occur. In contrast, the roadbed can act as a dam, blocking floodwater from inundating ecosystems on the other side. In the current study, this altered hydrology due to a roadbed-ditch system resulted in the conversion of what we termed healthy pond pine forest into actively transitioning ghost forest. The strong differences in species composition between the ghost forest and healthy forest was the result of this disturbance to the hydrologic and, potentially, the salinity regimes. The composition of wetland vegetation is strongly controlled by the wetland water level and hydroperiod [39,40]. Physical and environmental stressors may exclude several plant species, and the duration and intensity of flooding serves as environmental determinants of plant species composition [9]. Swamp bay, pond pine, red maple, and sweetgum are typical overstory tree species found within the Alligator River National Wildlife Refuge [41]. The healthy forest studied here was dominated by a pond pine overstory with the other species as associated sub-canopy co-dominants typical of much of the refuge. However, the adjacent ghost forest, just on the other side of the roadbed-ditch, was characterized by the almost complete mortality of the pine overstory, and the replacement of the understory by dense thickets of swamp bays and other woody shrubs. This type of ecosystem transition (replacement of forest by shrub-dominated systems) was also typical over much of the refuge, and was due to the shrubs having a higher flood tolerance, even when compared to the moderately flooded tolerant pond pine, as was reported for other similar systems [3].

According to personnel from the refuge and the ARNWR Comprehensive Management Plan [18], the roadbed-ditch system was constructed at the study site in 1965. However, it is interesting to note that the remotely-sensed signs of forest decline only began to appear after the mid-2000s (Figure 1). This suggests the environmental stress factors leading to large-scale ecosystem transition became severe only relatively recently. Although pond pine is considered an invader species in wetland coastal plain settings, it is unusual for this species to mature in waterlogged areas [42]. This supports our hypothesis that the $67 \%$ overstory mortality in the ghost forest could, at least in part, be due to the increasing inundation at the site in recent years. The decreasing canopy cover of the dying pond pine results in high understory light levels, allowing for very flood-tolerant swamp bays to flourish, changing the species composition. The continuing dominance of a pond pine overstory in the healthy forest implicates the roadbed-ditch system as a causative factor driving this ecosystem transition by slowing site drainage, thus lengthening the inundation period (hydroperiod), leading to tree mortality. However, the $54 \%$ mortality of swamp bays and other woody shrubs in the ghost forest, indicates that the hydrological stress is exceeding the tolerance limits of even these very flood-tolerant plants as part of the ecosystem transition to ghost forest. This suggests that the current shrub-dominance is only 
a transitory state, and that further ecosystem transition occurs with continuing increases in the severity of the driving environmental stress factors.

In addition to hydrologic stress, saltwater intrusion was implicated as a factor driving the formation of ghost forests along the southeast Atlantic and Gulf coasts [12]. In the early stages of saltwater intrusion, live trees may suffer reduced annual growth, and then forest distress becomes more visible. Young trees die conspicuously and new tree recruitment ceases $[43,44]$. This cessation of recruitment skews tree age distributions towards older age classes until these older remaining trees eventually die, forming relict trees that will become ghost forests. Although we did not measure salinity exposure regimes in the current study, accordingly, trees are most vulnerable to salinity stress during germination and as seedlings [45]. Additionally, even the most flood-tolerant species require periodic soil aeration for successful seed germination [3]. Therefore, the mortality occurring in our study may have been driven by the synergistic impacts of salinity and inundation, a similar condition reported by other studies [45-47]. High mortality rates and the subsequent large amount of forest carbon losses in coastal forests was attributed to sea level rise, drought [48], hurricane/storms [10,13], and hydrological connectivity from dams, ditching, and canals [49]. The increasingly apparent forest mortality and ecosystem transition, of which the current ghost forests appear to be at a seral stage, suggest that the environmental drivers recently surpassed the threshold of tolerance of coastal pond pine in eastern North Carolina, accelerated by the effects of human infrastructure on hydrology and, potentially, salinity regimes.

\subsection{Aboveground Biomass and Carbon Content of Vegetation}

The proliferation of swamp bays and the decline of overstory pines with ecosystem transition to ghost forests has implications for aboveground biomass and the carbon content of these coastal ecosystems. The capacity of forest ecosystems to store $\mathrm{C}$ in biomass varies depending on the species composition, age, and population density of each layer of the plant community, N:P ratio, total nutrient supply, morphological and physiological traits of plants, the amplitude of water level, water $\mathrm{pH}$ and electrical conductivity $[39,50]$. Despite the fact that the healthy forest had a higher average aboveground biomass on a per tree basis, the ghost forest, with a higher number trees of smaller diameter, had a higher total aboveground biomass than that of the road side. The intraspecific competition of trees in higher population densities usually led to a higher total aboveground carbon content [51].

We did not measure the water table depth in this study; however, a carbon flux monitoring station within ARNWR recorded a prolonged hydroperiod (2009-present) during non-growing seasons [52-54]. This monitoring station is located inland of the ARNWR [44]. Since our study plots were located in the outer part of ARNWR and were closer to a body of water (East Lake), we supposed our study sites would have experienced more severe, prolonged flooding than the carbon monitoring site. Hydrological conditions significantly influence wetland functioning [55]. Water level affects oxygen availability, decomposition rates, and nutrient mobilization from the sediment [56,57] and thus affects biomass production $[58,59]$. The water level also influences the ability of seeds to germinate and establish [60].

A healthy forest has a multi-layered structure that includes overstory, mid-story, and understory vegetation. Forest structure is a very critical component affecting natural tree regeneration and forest stability $[61,62]$. However, our results showed an imbalance in forest structure in both the ghost and healthy forest. The overstory trees have a far greater density than the mid-story and understory stratum. In the ghost forest, only a small percentage of regeneration species live past the mid-story stage, as shown by low biomass in the mid-story level (Table 3). An increase in overstory structure induces a reduction in mid-story or understory vegetation due to competition for resources such as light, nutrients, and space. Maintaining enough understory vegetation biomass should be considered in the management goals of any forest ecosystem. 
A higher overstory canopy density and biomass in both the ghost and healthy forests in our study ultimately has a negative effect on the understory layer. This negative impact significantly limits the restoration of proper stand structure in this wetland forest. However, there are also positive effects with rising overstory tree density as this increases the tree number, allocation fraction of photosynthetic products in stems, and the aboveground net primary productivity [63]. As a result of the interaction between the positive and negative effects of tree density, the aboveground biomass of trees increases with a higher tree density but at a declining rate after a period of time [51].

\subsection{Soil Carbon}

Our results confirmed the relevance of freshwater wetlands within ARNWR as a C sink. Total carbon (C) stocks in the study sites ranged from $749.0 \pm 170.5 \mathrm{Mg} \mathrm{ha}^{-1}$ in the healthy forest to $824.1 \pm 46.2 \mathrm{Mg} \mathrm{ha}^{-1}$ in the ghost forest. These values are higher than those published for other eastern Mountains and the Upper Midwest, averaging $478 \pm 58 \mathrm{Mg} \mathrm{ha}^{-1}$ to $539 \pm 47 \mathrm{Mg} \mathrm{ha}^{-1}$ in the top $100 \mathrm{~cm}$ soil depth [4]; $533 \mathrm{Mg} \mathrm{C} \mathrm{ha}^{-1}$ in organic wetlands of southeastern Atlantic coastal plains [64]; and $586 \mathrm{Mg} \mathrm{C} \mathrm{ha}^{-1}, 100 \mathrm{~cm}$ soil depth [65] in forested wetlands in New England, USA. Our total soil C was also higher than $\left(195 \pm 25 \mathrm{Mg} \mathrm{ha}^{-1}\right)$ that reported in the Interior Plains of the Dakota Praire [66,67] and $198 \pm 21$ and $216 \pm 30 \mathrm{Mg} \mathrm{ha}^{-1}$ in the Coastal Plains and West [4]; $340 \pm 94 \mathrm{Mg} \mathrm{ha}^{-1}$ in the Gulf of Mexico measured to soil depths of 100 and $200 \mathrm{~cm}$ [16]; $109 \mathrm{Mg} \mathrm{C} \mathrm{ha}^{-1}$ in flats and levees; and $193 \mathrm{Mg} \mathrm{C}$ ha-1 in mineral wetlands of the southeastern Atlantic coastal plains [64].

The depth of peat horizons is mainly determined by the activity of soil organisms, the repeated interruption of humus accumulation by water dynamics, soil micro-relief, the distance to bodies of water, production and decomposition dynamics, organic and mineral depositional history $[2,16]$, which might cause the low soil C stocks found in top 0-50 cm soil horizons in both the ghost and healthy forests. By contrast, the higher soil carbon below (50-100 cm depth) in our study indicates the episodic burial and preservation of soil C due to anaerobic soil conditions that slow the mineralization of the buried C [64]. However, a study reported that soil layers below $30 \mathrm{~cm}$ deep contain substantial cumulative reservoirs of carbon, with $65 \%$ of the total wetland soil carbon stored between 30 and $120 \mathrm{~cm} \mathrm{[4].} \mathrm{It}$ must be noted that we only determined $C$ stocks of up to a $100 \mathrm{~cm}$ depth and that total stocks may be even higher at deeper layers. Soil sampling in deeper layers is likely needed for the more effective evaluation and modeling of wetland soil carbon dynamics.

\subsection{Soil Accumulation over Time}

The organic sediment of the soils we analyzed was deposited over 1870 years, which indicated the soil's capacity to sequester $\mathrm{C}$ in the long-term (soil-carbon-memory effect) [2]. Fixed $\mathrm{C}$ may be released as $\mathrm{CO}_{2}$ by microorganisms during decomposition or stored belowground, where anaerobic decomposition occurs slowly, and recalcitrant $C$ may remain for millennia [16]. The ongoing delivery of sediment due to flooding leads to sediment deposition, the burial of organic matter, and the vertical accretion of marsh surfaces, thus allowing carbon to accumulate over long periods [4]. Increasing rates of sea level rise may also contribute to soil accretion by increasing the duration of inundation and increasing sediment deposition on marsh surfaces [68]. Anthropogenic impacts such as the presence of ditches and dikes also have a strong association with affecting soil carbon deposition [4]. A slightly lower soil carbon stored in the healthy forest might be due to the presence of ditches increasing stream and base flows, thereby increasing the annual discharge, which leads to lower (that is, drier) groundwater levels. This lower groundwater level over time could increase soil carbon oxidation and affect soil carbon stores [4]. More stored carbon in the ghost forest might be due to the occurrence of constantly saturated conditions, allowing for more efficient $\mathrm{C}$ mineralization at the soil surface and limiting microbial respiration at depth [64], and some contribution of dying overstory trees to soil $\mathrm{C}$ inputs. 
Our mean soil accumulation rate was $2.59 \mathrm{~mm}_{\text {year }}^{-1}$, yet we found a decreasing trend as our site aged closer to modern times some 235 to 265 years ago $\left(1.11 \mathrm{~mm}_{\text {year }}{ }^{-1}\right.$ to $1.31 \mathrm{~mm}$ year $^{-1}$ ) (Table 4 ). This decline in trend may occur because the vertical accretion rates overlap with the range of sea level rise rates. Numerical models predict that the maximum vertical accretions rates 2100 years ago were generally 5-30 $\mathrm{mm}^{\text {year }}{ }^{-1}$ [69]. Once these maximum limits are achieved, wetland drowning can be observed [12,70]. When these threshold rates of sea level rise are exceeded, wetlands must migrate laterally into submerging uplands to survive [12].

Vegetation at our site persisted for at least 1870 years, resisting drowning to sea level rise for many centuries because natural ecogeomorphic feedbacks allowed coastal habitats to vertically accrete and keep pace with the sea level [71]. However, a study reported that sea levels have risen at an average rate of $2.1 \mathrm{~mm}_{\text {year }}{ }^{-1}$, representing the steepest century-scale increase of the past two millennia [72], and this rate was initiated between AD 1865 and 1892. Another study also reported a rise in sea level from $2.2 \mathrm{~mm}_{\text {year }}{ }^{-1}$ to $2.4 \mathrm{~mm}_{\text {year }}{ }^{-1}$ around the 18th century [73]. If we follow the result of these studies with a sea level rise rate of $2.1 \mathrm{~mm}_{\text {year }}{ }^{-1}$ to $2.4 \mathrm{~mm}_{\text {year }}-1$, this means that the sediment accumulation in our study sites of less than $1.5 \mathrm{~mm}_{\text {year }}^{-1}$, during the turn of 18th century, was less than the estimated rate of sea level rise (2.1-2.4 $\mathrm{mm}^{-1 e a r^{-1}}$ ). These estimates suggest that our site may have already been slightly submerged long before and has transitioned from a depositional to an erosive environment and experienced a drowning effect [12], slowly migrating laterally towards uplands to survive as it approaches modern times. Recent global modeling suggests wetland migration into submerging uplands is the single most significant factor influencing wetland area over time, and that global wetland area could increase by up to $60 \%$ by 2100 for a $1.1 \mathrm{~m}$ sea level rise [74]. Our study site also appeared to be undergoing a transition from organic to mineral accumulation based on the decreased organic matter and sediment accumulation heading towards the open water. This stratigraphic sequence was indicative of submerging marsh [16].

Our estimated carbon accumulation rate (CAR) of $0.21-1.67 \mathrm{Mg}^{-1}$ year $^{-1}$ aged $^{-1}$ 235-1870 years old at both the ghost and healthy forests (Table 4 aligns with other studies conducted elsewhere in the United States. Johnson et al., 2007 [75] collected and aged a New England salt marsh core to 3700 cal BP and reported a CAR of $0.4 \mathrm{Mg} \mathrm{ha}^{-1} \mathrm{year}^{-1}$. Brevik and Homburg, 2004 [76] collected a core in Southern California that formed over the course of 5000 years and measured a CAR of $0.3 \mathrm{Mg} \mathrm{ha}^{-1}$ year $^{-1}$. Drexler, 2011 [77] measured CAR in cores $>6000$ years old and found CARs from 0.38 to $0.79 \mathrm{Mg} \mathrm{ha}^{-1}$ year $^{-1}$. A study also found a CAR of $0.39 \mathrm{Mg} \mathrm{ha}^{-1}$ year $^{-1}$ when integrated over $\sim 2400$ years at $2.2 \mathrm{~m}$ depth of salt marsh [25]. These results suggest that carbon storage in marshes can be enhanced by SLR-driven OM burial. We caution that our sampling sites only covered a few plots with a small sampling size, and our estimates came with some degree of uncertainty. Telford et al., 2004 [78] compared different age-depth modeling techniques for radiocarbon-dated sediments and found that uncertainty is often underestimated, and the errors were surprisingly large, especially when there were few dated levels.

\section{Conclusions}

Our study quantifies the impact of roadside ditching and drainage on ecosystem transition from pond pine to shrub pocosin along the lower coastal plain of North Carolina. Ditches and the roadbeds protect forest on the roadside but accelerates the ecosystem transition to a ghost forest on the ditch side, which has implications for the aboveground $\mathrm{C}$ storage and cycling. Our study helped us to better understand how coastal wetland soil carbon accumulation changed over time and the response mechanism of vegetation to these changing hydrological perturbations. Our investigation contributes to providing information on the current status and past trends in coastal wetland soil dynamics that may provide valuable insights into the future responses of the wetland ecosystems to sea level rise and climate change. The mismanagement of the wetland ecosystem may convert the present soil $\mathrm{C}$ pools into net $\mathrm{C}$ sources in the future. Therefore, conservation 
strategies for the wetland ecosystem should, to a greater extent, incorporate the functions of disturbed and undisturbed wetland forests as C sinks. Flood control structures prevented the migration of outer bank marshes into inland wetlands. The management of wetland ecosystems must therefore consider the cost of constructing more conventional flood control structures to the cost of damages associated with flooding and the danger of inland forested wetlands becoming ghost forests. Choices between defending the coast from sea level rise and facilitating ecosystem transition play a critical role in determining the fate and function of coastal wetland ecosystems. Accurate carbon accounting in wetlands is vital to reduce the risk of climate change contributions by identifying and protecting wetland landscapes that hold disproportionately large soil C stocks.

Author Contributions: Conceptualization, C.B. and J.K.; methodology, C.B. and J.K.; software, C.B. and M.A.; validation, K.M. and M.F.; formal analysis, M.A., O.J.I., D.H. and M.K.; Investigation, C.B., K.M. and M.F.; resources, J.K.; data curation, M.A., C.B., O.J.I., D.H. and M.K.; writing-original draft preparation, M.A. and C.B.; writing-review and editing, J.K., O.J.I., K.M., D.H. and M.K.; visualization, M.A.; supervision, A.N. and J.K.; project administration, A.N. and J.K.; funding acquisition, J.K. All authors have read and agreed to the published version of the manuscript.

Funding: Primary funding was provided by the USDA NIFA (Multi-agency A.5 Carbon Cycle Science Program) award 2014-67003-22068. Additional funding was provided by the DOE NICCR award 08-SC-NICCR-1072, the USDA Forest Service award 13-JV-11330110-081, and the DOE LBNL award DE-AC02-05CH11231. Work by MF was supported by project SustES-Adaptation strategies for sustainable ecosystem services and food security under adverse environmental conditions (CZ.02.1.01/0.0/0.0/16_019/0000797).

Institutional Review Board Statement: Not applicable.

Informed Consent Statement: Not applicable.

Data Availability Statement: Not applicable.

Conflicts of Interest: The authors declare no conflict of interest.

\section{References}

1. Mitra, S.; Wassmann, R.; Vlek, P.L.G. An Appraisal of Global Wetland Area and Its Organic Carbon Stock. Curr. Sci. 2005, 88, 25-35.

2. Cierjacks, A.; Kleinschmit, B.; Babinsky, M.; Kleinschroth, F.; Markert, A.; Menzel, M.; Ziechmann, U.; Schiller, T.; Graf, M.; Lang, F. Carbon Stocks of Soil and Vegetation on Danubian Floodplains. J. Plant Nutr. Soil Sci. 2010, 173, 644-653. [CrossRef]

3. Casey, W.P.; Ewel, K.C. Patterns of Succession in Forested Depressional Wetlands in North Florida, USA. Wetlands 2006, 26, 147-160. [CrossRef]

4. Nahlik, A.M.; Fennessy, M.S. Carbon Storage in US Wetlands. Nat. Commun. 2016, 7, 13835. [CrossRef]

5. Day, J.W.; Christian, R.R.; Boesch, D.M.; Yáñez-Arancibia, A.; Morris, J.; Twilley, R.R.; Naylor, L.; Schaffner, L.; Stevenson, C. Consequences of Climate Change on the Ecogeomorphology of Coastal Wetlands. Estuaries Coasts 2008, 31, 477-491. [CrossRef]

6. Horton, B.P.; Rahmstorf, S.; Engelhart, S.E.; Kemp, A.C. Expert Assessment of Sea-Level Rise by AD 2100 and AD 2300. Quat. Sci. Rev. 2014, 84, 1-6. [CrossRef]

7. Cormier, N.; Krauss, K.W.; Conner, W.H. Periodicity in Stem Growth and Litterfall in Tidal Freshwater Forested Wetlands: Influence of Salinity and Drought on Nitrogen Recycling. Estuaries Coasts 2013, 36, 533-546. [CrossRef]

8. Ensign, S.H.; Hupp, C.R.; Noe, G.B.; Krauss, K.W.; Stagg, C.L. Sediment Accretion in Tidal Freshwater Forests and Oligohaline Marshes of the Waccamaw and Savannah Rivers, USA. Estuaries Coasts 2014, 37, 1107-1119. [CrossRef]

9. Truus, L. Estimation of Above-Ground Biomass of Wetlands. In Biomass and Remote Sensing of Biomass; IntechOpen: London, UK, 2011. [CrossRef]

10. Stagg, C.L.; Schoolmaster, D.R.; Piazza, S.C.; Snedden, G.; Steyer, G.D.; Fischenich, C.J.; McComas, R.W. A Landscape-Scale Assessment of Above- and Belowground Primary Production in Coastal Wetlands: Implications for Climate Change-Induced Community Shifts. Estuaries Coasts 2017, 40, 856-879. [CrossRef]

11. Rasmussen, C.; Southard, R.J.; Horwath, W.R. Litter Type and Soil Minerals Control Temperate Forest Soil Carbon Response to Climate Change. Glob. Chang. Biol. 2008, 14, 2064-2080. [CrossRef]

12. Kirwan, M.L.; Gedan, K.B. Sea-Level Driven Land Conversion and the Formation of Ghost Forests. Nat. Clim. Chang. 2019, 9, 450-457. [CrossRef]

13. Hopkinson, C.S.; Lugo, A.E.; Alber, M.; Covich, A.P.; Van Bloem, S.J. Forecasting Effects of Sea-Level Rise and Windstorms on Coastal and Inland Ecosystems. Front. Ecol. Environ. 2008, 6, 255-263. [CrossRef] 
14. Neumann, B.; Vafeidis, A.T.; Zimmermann, J.; Nicholls, R.J. Future Coastal Population Growth and Exposure to Sea-Level Rise and Coastal Flooding-A Global Assessment. PLoS ONE 2015, 10, e0118571. [CrossRef]

15. White, E.; Kaplan, D. Restore or Retreat? Saltwater Intrusion and Water Management in Coastal Wetlands. Ecosyst. Health Sustain. 2017, 3, e01258. [CrossRef]

16. Elsey-Quirk, T.; Seliskar, D.M.; Sommerfield, C.K.; Gallagher, J.L. Salt Marsh Carbon Pool Distribution in a Mid-Atlantic Lagoon, USA: Sea Level Rise Implications. Wetlands 2011, 31, 87-99. [CrossRef]

17. Dreyer, G.D.; Niering, W.A. Bulletin No. 34: Tidal Marshes of Long Island Sound: Ecology, History and Restoration. Human Impacts on Tidal Wetlands: History and Regulations; Connecticut College Arboretum: New London, CT, USA, 1995; ISBN 1878899058.

18. Bryant, M.R.; Jerome, P.; Andrew, J.; Hamilton, S. Alligator River National Wildlife Refuge Comprehensive Conservation Plan; Fish and Wildlife Service, US Department of the Interior: Atlanta, GA, USA, 2008.

19. McKee, K.L. Biophysical Controls on Accretion and Elevation Change in Caribbean Mangrove Ecosystems. Estuar. Coast. Shelf Sci. 2011, 91, 475-483. [CrossRef]

20. Morris, J.T.; Sundareshwar, P.V.; Nietch, C.T.; Kjerfve, B.; Cahoon, D.R. Responses of Coastal Wetlands to Rising Sea Level. Ecology 2002, 83, 2869-2877. [CrossRef]

21. Kirwan, M.L.; Guntenspergen, G.R. Response of Plant Productivity to Experimental Flooding in a Stable and a Submerging Marsh. Ecosystems 2015, 18, 903-913. [CrossRef]

22. Pennings, S.C.; Grant, M.B.; Bertness, M.D. Plant Zonation in Low-Latitude Salt Marshes: Disentangling the Roles of Flooding, Salinity and Competition. J. Ecol. 2005, 93, 159-167. [CrossRef]

23. Holmquist, J.R.; Windham-Myers, L.; Bliss, N.; Crooks, S.; Morris, J.T.; Megonigal, J.P.; Troxler, T.; Weller, D.; Callaway, J.; Drexler, J.; et al. Accuracy and Precision of Tidal Wetland Soil Carbon Mapping in the Conterminous United States. Sci. Rep. 2018, 8, 9478. [CrossRef] [PubMed]

24. Bridgham, S.D.; Megonigal, J.P.; Keller, J.K.; Bliss, N.B.; Trettin, C. The Carbon Balance of North American Wetlands. Wetlands 2006, 26, 889-916. [CrossRef]

25. McTigue, N.; Davis, J.; Rodriguez, A.B.; McKee, B.; Atencio, A.; Currin, C. Sea Level Rise Explains Changing Carbon Accumulation Rates in a Salt Marsh Over the Past Two Millennia. J. Geophys. Res. Biogeosci. 2019, 124, 2945-2957. [CrossRef]

26. Riggs, S.R.; Ames, D. Drowning the North Carolina Coast: Sea-Level Rise and Estuarine Dynamics; NC Sea Grant: Raleigh, NC, USA, 2003.

27. Riggs, S.R.; Ames, D.V.; Culver, S.J.; Mallinson, D.J. Review Reviewed Work(s): The Battle for North Carolina's Coast: Evolutionary History, Present Crisis, and Vision for the Future. Southeast. Geogr. 2012, 52, 242-244. [CrossRef]

28. Minick, K.J.; Kelley, A.M.; Miao, G.; Li, X.; Noormets, A.; Mitra, B.; King, J.S. Microtopography Alters Hydrology, Phenol Oxidase Activity and Nutrient Availability in Organic Soils of a Coastal Freshwater Forested Wetland. Wetlands 2019, 39, 263-273. [CrossRef]

29. Burns, R.M.; Honkala, B.H. (Eds.) Bramlett DL Pond pine (Pinus serotinaMichx). In The Silvics of North America-Agricultural Handbook 654; USDA Forest Service: Washington, DC, USA, 1990.

30. FIA. Phase 3Field Guide_Down Woody Materials, Section 25; Down Woody Materials; USDA: Kansas City, MO, USA, 2007.

31. Jenkins, J.C.; Chojnacky, D.C.; Heath, L.S.; Birdsey, R.A. Comprehensive Database of Diameter-Based Biomass Resgressions for North American Tree Species; United States Department of Agriculture, Forest Service, Northeastern Research Station: Kansas City, MO, USA, 2003.

32. Preston, R.J.; Braham, R.R. North American Trees; Iowa State Press: Ames, IA, USA, 2002.

33. Hajdas, I.; Hendriks, L.; Fontana, A.; Monegato, G. Evaluation of Preparation Methods in Radiocarbon Dating of Old Wood. Radiocarbon 2017, 59, 727-737. [CrossRef]

34. Wickham, H. Ggplot2: Elegant Graphics for Data Analysis; Springer: New York, NY, USA, 2016; ISBN 978-3-319-24277-4.

35. Sievert, C. Interactive Web-Based Data Visualization with R, Plotly, and Shiny; Chapman and Hall/CRC: Boca Raton, FL, USA, 2020; ISBN 9781138331457.

36. Wickham, H.; Averick, M.; Bryan, J.; Chang, W.; McGowan, L.; François, R.; Grolemund, G.; Hayes, A.; Henry, L.; Hester, J.; et al. Welcome to the Tidyverse. J. Open Source Softw. 2019, 4, 1686. [CrossRef]

37. Wickham, H. Reshaping Data with the Reshape Package. J. Stat. Softw. 2007, 12, 1-20.

38. R Core Team. R: A Language and Environment for Statistical Computing; R Foundation for Statistical Computing: Vienna, Austria, 2021.

39. Ilomets, M.; Truus, L.; Pajula, R.; Sepp, K. Species Composition and Structure of Vascular Plants and Bryophytes on the Water Level Gradient within a Calcareous Fen North Estonia. Est. J. Ecol. 2010, 59, 19-38. [CrossRef]

40. Wilcox, D.A.; Nichols, S.J. The Effects of Water-Level Fluctuations on Vegetation in a Lake Huron Wetland. Wetlands 2008, 28, 487-501. [CrossRef]

41. Aguilos, M.; Mitra, B.; Noormets, A.; Minick, K.; Prajapati, P.; Gavazzi, M.; Sun, G.; McNulty, S.; Li, X.; Domec, J.C.; et al. Long-Term Carbon Flux and Balance in Managed and Natural Coastal Forested Wetlands of the Southeastern USA. Agric. For. Meteorol. 2020, 288-289, 108022. [CrossRef]

42. Craine, S.I.; Orians, C.M. Pitch Pine (Pinus Rigida Mill.) Invasion of Cape Cod Pond Shores Alters Abiotic Environment and Inhibits Indigenous Herbaceous Species. Biol. Conserv. 2004, 116, 181-189. [CrossRef] 
43. Williams, K.; Ewel, K.C.; Stumpf, R.P.; Putz, F.E.; Workman, T.W. Sea-Level Rise and Coastal Forest Retreat on the West Coast of Florida, USA. Ecology 1999, 80, 2045-2063. [CrossRef]

44. Begin, Y. The Effects of Shoreline Transgression on Woody Plants, Upper St Lawrence Estuary, Quebec. J. Coast. Res. 1990, 6, 815-827.

45. Pezeshki, S.R.; Delaune, R.D.; Patrick, W.H. Flooding and Saltwater Intrusion: Potential Effects on Survival and Productivity of Wetland Forests along the U.S. Gulf Coast. For. Ecol. Manag. 1990, 33-34, 287-301. [CrossRef]

46. Lennard-Barrett, E.G. The Interaction between Waterlogging and Salinity in Higher Plants: Causes, Consequences and Implications. Plant Soil 2003, 253, 35-54. [CrossRef]

47. Conner, W.H. The Effect of Salinity and Waterlogging on Growth and Survival of Baldcypress and Chinese Tallow Seedlings; Coastal Education \& Research Foundation, Inc.: Lawrence, KS, USA, 1994; Volume 10, pp. 1045-1049. Available online: https:/ / www. Jstor.Org/Stable/4298295 (accessed on 15 August 2021).

48. Desantis, L.R.G.; Bhotika, S.; Williams, K.; Putz, F.E. Sea-Level Rise and Drought Interactions Accelerate Forest Decline on the Gulf Coast of Florida, USA. Glob. Chang. Biol. 2007, 13, 2349-2360. [CrossRef]

49. Poulter, B.; Goodall, J.L.; Halpin, P.N. Applications of Network Analysis for Adaptive Management of Artificial Drainage Systems in Landscapes Vulnerable to Sea Level Rise. J. Hydrol. 2008, 357, 207-217. [CrossRef]

50. Mendoza-Ponce, A.; Galicia, L. Aboveground and Belowground Biomass and Carbon Pools in Highland Temperate Forest Landscape in Central Mexico. Forestry 2010, 83, 497-506. [CrossRef]

51. Ile, O.J.; Aguilos, M.; Morkoc, S.; Minick, K.; Domec, J.-C.; King, J.S. Productivity of Low-Input Short-Rotation Coppice American Sycamore (Platanus Occidentalis L.) Grown at Different Planting Densities as a Bioenergy Feedstock over Two Rotation Cycles. Biomass Bioenergy 2021, 146, 105983. [CrossRef]

52. Aguilos, M.; Sun, G.; Noormets, A.; Domec, J.C.; McNulty, S.; Gavazzi, M.; Prajapati, P.; Minick, K.J.; Mitra, B.; King, J. Ecosystem Productivity and Evapotranspiration Are Tightly Coupled in Loblolly Pine (Pinus Taeda L.) Plantations along the Coastal Plain of the Southeastern U.S. Forests 2021, 12, 1123. [CrossRef]

53. Aguilos, M.; Sun, G.; Noormets, A.; Domec, J.C.; McNulty, S.; Gavazzi, M.; Minick, K.; Mitra, B.; Prajapati, P.; Yang, Y.; et al. Effects of Land-Use Change and Drought on Decadal Evapotranspiration and Water Balance of Natural and Managed Forested Wetlands along the Southeastern US Lower Coastal Plain. Agric. For. Meteorol. 2021, 303, 108381. [CrossRef]

54. Minick, K.J.; Mitra, B.; Li, X.; Fischer, M.; Aguilos, M.; Prajapati, P.; Noormets, A.; King, J.S. Wetland Microtopography Alters Response of Potential Net $\mathrm{CO}_{2}$ and $\mathrm{CH}_{4}$ Production to Temperature and Moisture: Evidence from a Laboratory Experiment. Geoderma 2021, 402, 115367. [CrossRef]

55. Ketcheson, S.J.; Price, J.S.; Carey, S.K.; Petrone, R.M.; Mendoza, C.A.; Devito, K.J. Constructing Fen Peatlands in Post-Mining Oil Sands Landscapes: Challenges and Opportunities from a Hydrological Perspective. Earth-Sci. Rev. 2016, 161, 130-139. [CrossRef]

56. Lamers, L.P.M.; van Diggelen, J.M.H.; Op Den Camp, H.J.M.; Visser, E.J.W.; Lucassen, E.C.H.E.T.; Vile, M.A.; Jetten, M.S.M.; Smolders, A.J.P.; Roelofs, J.G.M. Microbial Transformations of Nitrogen, Sulfur, and Iron Dictate Vegetation Composition in Wetlands: A Review. Front. Microbiol. 2012, 3, 156. [CrossRef]

57. Harpenslager, S.F.; van den Elzen, E.; Kox, M.A.R.; Smolders, A.J.P.; Ettwig, K.F.; Lamers, L.P.M. Rewetting Former Agricultural Peatlands: Topsoil Removal as a Prerequisite to Avoid Strong Nutrient and Greenhouse Gas Emissions. Ecol. Eng. 2015, 84, 159-168. [CrossRef]

58. Sarneel, J.M.; Geurts, J.J.M.; Beltman, B.; Lamers, L.P.M.; Nijzink, M.M.; Soons, M.B.; Verhoeven, J.T.A. The Effect of Nutrient Enrichment of Either the Bank or the Surface Water on Shoreline Vegetation and Decomposition. Ecosystems 2010, 13, 1275-1286. [CrossRef]

59. Dee, S.M.; Ahn, C. Plant Tissue Nutrients as a Descriptor of Plant Productivity of Created Mitigation Wetlands. Ecol. Indic. 2014, 45, 68-74. [CrossRef]

60. Overbeek, C.C.; Harpenslager, S.F.; van Zuidam, J.P.; van Loon, E.E.; Lamers, L.P.M.; Soons, M.B.; Admiraal, W.; Verhoeven, J.T.A.; Smolders, A.J.P.; Roelofs, J.G.M.; et al. Drivers of Vegetation Development, Biomass Production and the Initiation of Peat Formation in a Newly Constructed Wetland. Ecosystems 2020, 23, 1019-1036. [CrossRef]

61. Suchar, V.A.; Crookston, N.L. Understory Cover and Biomass Indices Predictions for Forest Ecosystems of the Northwestern United States. Ecol. Indic. 2010, 10, 602-609. [CrossRef]

62. Kumar, P.; Chen, H.Y.H.; Thomas, S.C.; Shahi, C. Linking Resource Availability and Heterogeneity to Understorey Species Diversity through Succession in Boreal Forest of Canada. J. Ecol. 2018, 106, 1266-1276. [CrossRef]

63. Litton, C.M.; Ryan, M.G.; Knight, D.H. Effects of Tree Density and Stand Age on Carbon Allocation Patterns in Postfire Lodgepole Pine. Ecol. Appl. 2004, 14, 460-475. [CrossRef]

64. Ricker, M.C.; Lockaby, B.G. Soil Organic Carbon Stocks in a Large Eutrophic Floodplain Forest of the Southeastern Atlantic Coastal Plain, USA. Wetlands 2015, 35, 291-301. [CrossRef]

65. Davis, A.A.; Stolt, M.H.; Compton, J.E. Spatial Distribution of Soil Carbon in Southern New England Hardwood Forest Landscapes. Soil Sci. Soc. Am. J. 2004, 68, 895-903. [CrossRef]

66. Gleason, R.A.; Laubhan, M.K.; Euliss, N.H. Ecosystems Services Derived from Wetland Conservation Practices in the United States Prairie Pothole Region with an emphasis on the U.S. Department Of Agriculture Conservation Reserve and Wetlands Reserve Programs; U.S. Geological Survey Professional Paper 1745; U.S. Geological Survey: Liston, VA, USA, 2008; 58p, ISBN 9781411320178. 
67. Johnston, C.A. Wetland Losses Due to Row Crop Expansion in the Dakota Prairie Pothole Region. Wetlands 2013, $33,175-182$. [CrossRef]

68. Mudd, S.M.; Howell, S.M.; Morris, J.T. Impact of Dynamic Feedbacks between Sedimentation, Sea-Level Rise, and Biomass Production on near-Surface Marsh Stratigraphy and Carbon Accumulation. Estuar. Coast. Shelf Sci. 2009, 82, 377-389. [CrossRef]

69. Kirwan, M.L.; Temmerman, S.; Skeehan, E.E.; Guntenspergen, G.R.; Fagherazzi, S. Overestimation of Marsh Vulnerability to Sea Level Rise. Nat. Clim. Chang. 2016, 6, 253-260. [CrossRef]

70. Crosby, S.C.; Sax, D.F.; Palmer, M.E.; Booth, H.S.; Deegan, L.A.; Bertness, M.D.; Leslie, H.M. Salt Marsh Persistence Is Threatened by Predicted Sea-Level Rise. Estuar. Coast. Shelf Sci. 2016, 181, 93-99. [CrossRef]

71. Kirwan, M.L.; Megonigal, J.P. Tidal Wetland Stability in the Face of Human Impacts and Sea-Level Rise. Nature 2013, 504, 53-60. [CrossRef]

72. Kemp, A.C.; Kegel, J.J.; Culver, S.J.; Barber, D.C.; Mallinson, D.J.; Leorri, E.; Bernhardt, C.E.; Cahill, N.; Riggs, S.R.; Woodson, A.L.; et al. Extended Late Holocene Relative Sea-Level Histories for North Carolina, USA. Quat. Sci. Rev. 2017, 160, 13-30. [CrossRef]

73. Kopp, R.E. Does the Mid-Atlantic United States Sea Level Acceleration Hot Spot Reflect Ocean Dynamic Variability? Geophys. Res. Lett. 2013, 40, 3981-3985. [CrossRef]

74. Schuerch, M.; Spencer, T.; Temmerman, S.; Kirwan, M.L.; Wolff, C.; Lincke, D.; McOwen, C.J.; Pickering, M.D.; Reef, R.; Vafeidis, A.T.; et al. Future Response of Global Coastal Wetlands to Sea-Level Rise. Nature 2018, 561, 231-234. [CrossRef]

75. Johnson, B.J.; Moore, K.A.; Lehmann, C.; Bohlen, C.; Brown, T.A. Middle to Late Holocene Fluctuations of C3 and C4 Vegetation in a Northern New England Salt Marsh, Sprague Marsh, Phippsburg Maine. Org. Geochem. 2007, 38, 394-403. [CrossRef]

76. Brevik, E.C.; Homburg, J.A. A 5000 Year Record of Carbon Sequestration from a Coastal Lagoon and Wetland Complex, Southern California, USA. Catena 2004, 57, 221-232. [CrossRef]

77. Drexler, J.Z. Peat Formation Processes through the Millennia in Tidal Marshes of the Sacramento-San Joaquin Delta, California, USA. Estuaries Coasts 2011, 34, 900-911. [CrossRef]

78. Telford, R.J.; Heegaard, E.; Birks, H.J.B. All Age-Depth Models Are Wrong: But How Badly? Quat. Sci. Rev. 2004, $23,1-5$. [CrossRef] 